\title{
Fog-water harvesting along the West Coast of South Africa: A feasibility study
}

\author{
J Olivier \\ Department of Anthropology, Archaeology, Geography and Environmental Studies, University of South Africa, PO Box 392, \\ UNISA 0003, South Africa
}

\begin{abstract}
Many parts of the West Coast of South Africa experience severe water shortages throughout the year. Despite the meager rainfall, however, the region is subject to a high incidence of fog which might provide water for water-poor communities. This paper investigates the fog water potential of the area. Since fog water collection rates are to some extent dependent upon the spatial and temporal characteristics of fog, these aspects were investigated. Pilot fog collectors were erected at six West Coast sites and the water collection rates measured over a three to four year period. It was found that the incidence of fog is mostly confined to the coastal zone below the $200 \mathrm{~m}$ contour line with fog frequency decreasing with latitude within this zone. The highest water collection rates were recorded at Cape Columbine where volumes in excess of $2.5 \mathrm{l} / \mathrm{m}^{2}$ of collecting surface can be expected to be collected per day. Of this, approximately $90 \%$ is due to fog deposition alone, while rainfall contributes to the remaining $10 \%$. The quality of the water is good and fit for human consumption.
\end{abstract}

\section{Introduction}

The West Coast of South Africa is one of the most arid parts of the country with the annual rainfall rarely exceeding $250 \mathrm{~mm}$ (South African Weather Bureau (SAWB), 1986). Only three perennial rivers traverse the area, namely, the Orange, Olifants and Berg Rivers, with the flow in other smaller rivers varying seasonally and usually having dry beds in summer. Although a number of communities make use of river water either through direct extraction or via pipelines or canals, the main source of water is groundwater through either boreholes, wells or fountains (Rush et al., 2000). This is, unfortunately, not always available in sufficient quantities and is often contaminated with naturally occurring salts or heavy metals (Toens et al., 1999). In view of the high population growth in rural areas and the expected boom in West Coast tourism, it is evident that pressure on existing limited water resources will increase in future. It is clear that there is an urgent need to identify alternative sources of potable water.

Fog is one such source of water. Although its water yielding potential is largely ignored by water provision authorities, it was used extensively in ancient times. The inhabitants of Palestine, for example, built small low circular honeycombed walls around their vines so that the mist and dew could precipitate in the immediate vicinity of the plants (Nelson-Esch, nd). Historically, both dew and fog were collected in the Atacama and other deserts from piles of stones, arranged so that the condensation would drip to the inside of the base of the pile where it was shielded from the day's sunshine (Linacre and Hobbs, 1977). In the Canary Islands, fog drip from trees was the sole source of water for man and animals for many years (Kerfoot, 1968).

One of the earliest documented experiments aimed at determining the volume of fog deposition was conducted by Marloth between 1901 and 1904. He attempted to measure the volume of fog water intercepted by vegetation on Table Mountain by making use of two rain gauges - one was left open in the usual

012 429-6452; fax 012 429-6; e-mail: olivij@unisa.ac.za Received 31 October 2001; accepted in revised form 3 September 2002. manner while a bunch of reeds was suspended above the other. Between November 1901 and mid-February 1903 the rain gauge collected $126 \mathrm{~mm}$ of water while the gauge with the reeds collected $2028 \mathrm{~mm}$ (Marloth 1904, 1907). Since then, it has become standard practice to measure fog precipitation by means of two rain gauges, with a fog-catcher of various designs attached to one of them. Many such experiments have been conducted - the most noteworthy in South Africa and Namibia being by Nagel (1959, 1962), Schutte (1971), Schulze (1975), Nieman et al., (1978) and Snow (1985). All these experiments indicated the considerable potential of fog as a water source.

A number of projects have been initiated which specifically aimed at supplying fog water to communities. The first was implemented at Mariepskop in Mpumalanga, South Africa, during 1969/70 (Schutte, 1971). It was used as an interim measure to supply water to the South African Air Force personnel manning the Mariepskop radar station. Two large fog screens, constructed from a plastic mesh and measuring $28.0 \times 3.6 \mathrm{~m}$ each, were erected at right angles to each other and to the fog-and cloud-bearing NE and SE winds. During a 15-month period, from October 1969 to December 1970, the screens collected an average of 31000 of water per month i.e. approximately $11 \mathrm{\ell} / \mathrm{m}^{2} \cdot \mathrm{d}$. When yields for only foggy days were taken into account, the mean was $23395 \ell$ per month - almost $800 \mathrm{l} / \mathrm{d}$. During the entire period, fog/cloud precipitation exceeded rainfall by a factor of 4.6 but during certain months it was up to 17 times greater (Schutte, 1971).

The second and largest fog water collection project to date was initiated by researchers at the National Catholic University of Chile and the International Development Research Centre in Canada, at a small fishing village in northern Chile in 1987. Here, 75 fog collectors, each measuring $12 \times 4 \mathrm{~m}$ were erected on a hill overlooking a small fishing village called Chungungo. According to reports, production rates vary from zero on clear days to a maximum of $100000 \ell / d$. With this arrangement, each of the 330 villagers received about $33 \ell$ of clean water per person per day (Schemenauer et al., 1988; Cereceda et al., 1992; Cereceda and Schemenauer, 1993; Schemenauer and Cereceda, 1991; 1994a). In view of the success of this project, similar fog water collection 
systems have been erected in the Canary Islands, Peru, Ecuador and the Sultanate of Oman (Schemenauer and Cereceda, 1994a).

Since the climates of the dry littoral zones in South Africa and Chile are quite similar with regards to major oceanic and atmospheric circulations and associated weather conditions (Lydolph, 1957), it seems likely that fog harvesting could also be successfully practiced along the West Coast of South Africa. A project, funded by the South African Water Research Commission (WRC) and aimed at investigating the feasibility of using fog water to supplement existing supplies in the rural areas of south Africa was initiated in 1995. Two regions were targeted, namely, the mountains of the eastern escarpment and the West Coast region. This paper describes the project in the latter region.

The two most important factors determining the feasibility of implementing a fog water collection are the expected yield and the quality thereof. These depend on the moisture content of the fog, the duration and frequency of fog events and on the speed of the wind (Nagel, 1956). They, in turn, depend on altitude and on the presence of certain regional climatic factors such as the pressure distribution in the area and the sea surface temperature. The direction and speed of the wind are also affected by the type of terrain and on the microtopography of the area (Schemenauer et al., 1987; Cereceda and Schemenauer, 1988). It follows that a first step in assessing the feasibility of using fog water as a supplementary water source is the determination of the spatial and temporal occurrence patterns of fog in the area and the establishment of the relationships between fog water yields and the various factors affecting it. Therefore, aspects which receive attention in this paper. They are:

The spatial and temporal fog patterns along the West Coast - so as to determine where fog occurs, how often it occurs, when it occurs and how persistent each fog episode is.

The collection and measurement of fog water yields at various sites.

The determination of fog water quality.

The methodology used for each will be discussed in the relevant section.

\section{West Coast fog}

The spatial and temporal characteristics of fog along the West Coast can be explained in terms of both the prevailing climatic conditions and the predominant fog type. The majority of authors agree that advection sea fog predominates in this area (Heydoorn and Tinley, 1980; Henderson-Sellers and Robinson, 1986), although radiation fog, inversion fog and cloud interception may also occur The sea fog results from the advection of relatively warm moist air over the cold water of the Benguela-Upwelling zone (PrestonWhyte and Tyson, 1988) - the latter being created by the circulation around the South Atlantic Anticyclone situated to the west of the subcontinent (Nelson and Hutchings, 1983). South-southwesterly winds on the eastern perimeter of the anticyclone blow parallel to the coast and, together with the deflection caused by Coriolis force, transport the surface waters away from the land. This results in cold, deep water welling upwards to re-establish equilibrium. The coldest water is thus found immediately adjacent to the coast. This zone of upwelling is dynamic and its extent varies considerably depending on season and prevailing weather conditions (Walker et al., 1984; Shannon, 1985; Lutjeharms and Meeuwis, 1987; Stockton, 1988).

Inland fog in the littoral zone of the West Coast may result from various processes. Firstly, fog formed along the coast may be advected inland. Such fog will dissipate quickly as the day progresses unless the cloud bank is very thick and onshore winds continue throughout the day. Secondly, during winter, moist air advected from the sea may be trapped below a surface inversion in valleys and hollows and cooled by nocturnal radiation to form valley fog. Estie (1984) suggests that this would be a diurnal phenomenon as the nocturnal land breeze would counter any onshore airflow. Considering that the South African West Coast is influenced by similar synoptic and local weather conditions as the Namibian coast, it is likely that cloud interception will also be active at higher elevation sites (Lancaster et al., 1984; Vendrig, 1990). Stratus clouds may be transported inland by westerly winds whereupon the cloud base may be lowered through convective overturning and radiation losses (Estie, 1986). In this way the stratus clouds may engulf high elevation areas, resulting in fog.

Although different fog types predominate in different areas, this does not preclude the possibility that numerous fog types may occur within any given region.

\section{Determination of spatial and temporal characteristics of West Coast fog}

Due to the variability of fog over short distances, the determination of spatial fog patterns is neither straightforward nor easy. In South Africa this is exacerbated by the paucity of fog recording stations - especially in the more sparsely populated parts of the country. The interpolation of fog incidence between stations is therefore extremely difficult and a map resulting from this method is not ideal and cannot be regarded as detailed or accurate. Notwithstanding these limitations, a fog incidence map (Fig. 1) was compiled which illustrates, to some extent, the spatial patterns of fog incidence along the West Coast.

\section{Data and method}

The principal data source for these compilations was the Weather Bureau publication, WB 40 (South African Weather Bureau (SAWB), 1986). Eleven stations are located within the region, of which three, namely Cape Columbine, Port Nolloth and Alexander Bay, are first order weather stations. Such stations are manned by part-time meteorological officers, with observations being made daily at 08:00, 14:00 and 20:00 (SAWB, 1987). The locations of the 10 stations are indicated on Fig. 1.

Each station's mean annual Fog Day Frequency (FDF) was transferred onto a base map and isopleths drawn by interpolation in order to link points with similar FDF values. In an attempt to improve the accuracy of the fog distribution map, use was made of information from personal observations of a number 'Fog Watchers' - a group of helpers who undertook to record the incidence and duration of fog episode during 1994 and 1995. Analysis of the latter data base revealed that there was some correspondence between fog incidence and elevation. Based on this information, contour lines were used to guide fog isopleths in the areas where data were lacking. In the vicinity of Cape Columbine where the coastal plain widens, the fog isolines exhibit a similar outward bulge. Cognisance was also taken of the influence of water bodies when drawing isopleths. The resulting map is shown as Fig. 1. An annual fog day frequency time series has been included for the three first order stations in order to show the variation of fog incidence over time.

A similar procedure was used to determine the seasonality of fog. Average monthly FDFs for the 10 South African Weather Bureau stations were extracted from WB40 (SAWB, 1986) and used to calculate seasons of high FDF for each station. The seasonal fog patterns for the three first order stations are indicated on the right hand side of Fig. 1. 


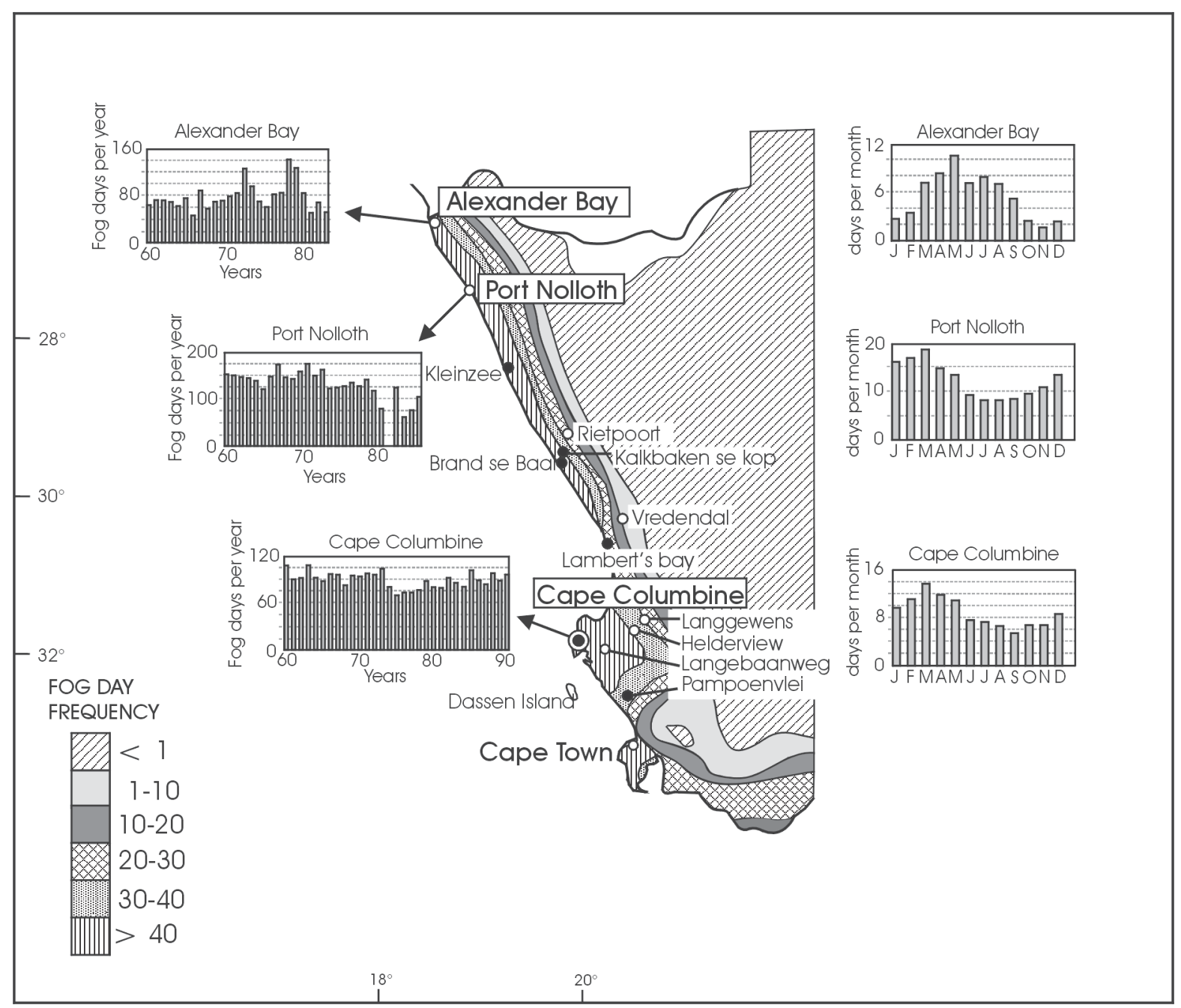

Figure 1

Spatial and temporal (annual and seasonal) fog distribution in patterns in South Africa $\mathrm{O}=$ Weather Bureau stations; $\bullet$ = experimental sites

Other temporal data such as diurnal fog incidence patterns, the duration of fog episodes and their intensity characteristics were only available for Alexander Bay, Port Nolloth and Cape Columbine. The data source comprised SAWB printouts for the period 1960 to 1990 . The printouts comprised daily fog occurrence records for the 1960 to 1977 period and past weather records for the post- 1977 period. In the former period, fog intensity was indicated by means of the codes 0,1 and 2 indicating light, moderate and heavy fog, respectively. These codes were based on horizontal visibilities ranging from 600 to $1000 \mathrm{~m}$ for light fogs, 300 to $600 \mathrm{~m}$ for moderate fogs and less than $300 \mathrm{~m}$ for dense fogs. After 1977 the intensity codes were replaced by data indicating the time period during which fog was recorded at a specific site. The discussion on fog intensity in South Africa is thus based on analysis of the 1960 to 1977 data, while for the diurnal patterns, data for the post-1977 period were used.

These data were also supplemented with information obtained from the Fog Watchers at Cape Columbine, Lamberts Bay, Rooiheuwel and Langklip. The latter two are farms in the vicinity of Velddrif. Limited amounts of data were obtained from the Namakwa Sands Mining Company's weather stations at Brand se Baai and Kalkbaken se Kop. Since fog incidence data for Cape Columbine, Lambert's Bay, Rooiheuwel and Langklip were recorded by observers, little information was available for the period between 20:00 and 06:00 whereas continuous data records were available where data loggers were used to record data.

\section{Results}

\section{Spatial fog characteristics}

Figure 1 indicates that, in general, the annual fog incidence decreases with increasing latitude and longitude. The mean annual fog day frequency increases from $66 \mathrm{~d}$ per year at Dassen Island to $111 \mathrm{~d}$ at Cape Columbine, to $148 \mathrm{~d}$ at Port Nolloth (SAWB, 1986). Longitudinally, the zone with highest FDFs abuts the coast, decreasing with distance from the sea. This accords with observations for the Namib and other west coast deserts (Copenhagen, 1953; Meigs, 1966; Lancaster et al., 1984; Olivier, 1992, 1995). As is the case in the Namib (Olivier, 1992, 1995), high fog occurrence along the west coast of South Africa appears to be limited to the coastal plain at elevations below the $200 \mathrm{~m}$ contour line. This is borne out by the data collected by the Fog Watchers. The link between topography and fog incidence can further be illustrated by comparison of the frequencies of fog at Vredendal and Garies. Although both stations lie approximately $30 \mathrm{~km}$ inland, 
Vredendal, with an elevation of $34 \mathrm{~m}$ above Mean Sea Level, has a fog frequency of $44 \mathrm{~d} / \mathrm{a}$ while Garies, which lies at $287 \mathrm{~m}$ above Mean Sea Level, experiences an average of only 0.6 fog days per annum (fd/a). However, within the foggy zone, fog occurs more frequently at sites with a slightly higher elevation than sea level. This was confirmed by independent tests carried out by the environmental officer of the Namakwa Sands Mining Co. The decrease in fog incidence with distance from the sea probably explains the lower annual fog day frequency at Alexander Bay

(67 d) since this station is located a few kilometers inland.

\section{Temporal patterns}

Not only does the FDF vary markedly over space, it is also extremely variable over time. This variability is evident in the annual, seasonal and diurnal fog incidence patters; in the duration of fog events; and in the fog intensity patterns at the three first order fog recording stations.

\section{Interannual variability}

The histograms superimposed on Fig. 1 and the statistics shown in Table 1 give some indication of the inter-annual variability at the stations. No identifiable pattern could be discerned from any of the annual time series. This may be due to the limited extent of the available data. It is, however, noticeable that Cape Columbine has the lowest inter-annual variability. This can probably be ascribed to the semi-permanent upwelling cell located in this region (Currie, 1953; Shannon, 1985; Lutjeharms and Meeuwis, 1987).

\section{Seasonality}

The West Coast receives rain mostly during the winter and spring months. The main fog season, by contrast, tends towards a summer to summer-autumn regime (Fig.1). At Cape Columbine, fog occurs most frequently during March, April and May, with fog incidence being lowest during September. Dassen Island (not shown in Fig. 1) shows essentially the same pattern, with maximum fog incidence occurring during February, March and April. At Port Nolloth, fog incidence also exhibits a summer-autumn maximum. However, the fog season tends more towards a winter regime to the north, the months with the highest probability of fog at Alexander Bay being April, May and July (SAWB, 1986). This autumn-winter fog seasonality extends northwards along the Namibian coast (Lancaster et al., 1984; Olivier, 1992). These variations are probably related to the position of the South Atlantic Anticyclone and the associated zone of upwelling.

The inland location of Alexander Bay may also influence the seasonal occurrence of fog. A difference in fog seasonality between coastal and inland sites is also evident elsewhere in the country. In the Cape Peninsula, for example, Cape Point has a distinct summer-autumn fog season whereas stations located further inland such as Cape Town International airport, Kirstenbosch and Observatory have autumn-winter fog maxima (Olivier and Van Heerden, 1999). This discrepancy is probably due to the fact that inland areas are more likely to experience radiation fog - especially on winter mornings following the passage of a cold front when clear skies, low minimum temperatures and high atmospheric humidity prevail. A change in fog seasonality is also evident in the Namib, but there. the fog season changes from an autumn-winter regime at the cast to a spring-summer maximum further inland (Nagel, 1959; Lancaster et al., 1984; Olivier, 1992).
TABLE 1

Summary of annual fog day frequency statistics at three first order stations on the West Coast (1954 - 1986)

\begin{tabular}{|l|c|c|c|c|c|}
\hline Station & Mean & Max & Min & Std dev & $\begin{array}{c}\text { Coeff. of } \\
\text { variation } \\
(\%)\end{array}$ \\
Alexander Bay & $83.9(67)$ & 145 & 49 & 24 & 28 \\
Port Nolloth & $139.2(148)$ & 180 & 64 & 28.8 & 20 \\
Cape Columbine & $107.6(111)$ & 130 & 76 & 13.8 & 12.8 \\
\hline
\end{tabular}

Values in brackets are SAWB (1986) long-term means

\section{Diurnal fog incidence}

Fog occurs most often during the cooler nocturnal hours, peaking between midnight and 08:00 and dissipating soon after 09:00 with the onset of fog mostly confined to the period after midnight. This is probably due to the prevalence of a land breeze during the night which inhibits landward movement of air. Comparisons of coastal and inland sites reveal minor differences. For instance, at the coastal sites, the maximum frequency of fog occurrence is between 05:00 and 07:00 while towards the interior this occurs slightly later, between 06:00 and 08:00. This indicates that peak incidence does not necessarily show an inverse relation with the diurnal thermal rhythm but may be influenced by the onset of the sea breeze. Also, the coastal sites are more likely to have fog throughout the day while fog tends to disappear by midmorning further inland.

\section{Duration of fog episodes}

It should be kept in mind that it was not possible to determine the exact times of the commencement and cessation of fog events from the Fog Watch or SAWB data. Consequently, it was assumed that fog which was recorded during any particular period, for instance the 00:00 to 08:00 period, started at midnight and lasted until 08:00. Despite these inaccuracies, the data could be used for comparisons between different recording stations.

Analysis of data obtained from the Fog Watchers indicted that fog episodes usually lasted for a period of two to six hours at both coastal and inland sites. Since advection sea fog tends to be more persistent than radiation fog, it was expected that coastal sites would have longer fog episodes. However, the longest fog episode was recorded inland at Rooiheuwel, where foggy conditions persisted for 55 h during April, 1994. This can probably be ascribed to the persistence of fog at higher altitudes.

Analysis of SAWB data revealed that at Port Nolloth, the longest fog episode lasted for 60 consecutive hours. Not only was the duration of fog episodes at Alexander Bay shorter that at Port Nolloth, but episodes of $24 \mathrm{~h}$ or more occurred less often at the former station. During the 1978 to 1985 period, for instance, there were 118 occasions when fog persisted throughout the day at Port Nolloth in comparison to only 30 such occasions at Alexander Bay.

South African Weather Bureau past weather data were used to compare the duration of fog episodes during a year with high fog incidence vs a low fog year at Port Nolloth. This revealed that fog episodes lasted longer during foggy years. For example, during a low fog year (1987), the majority of fog episodes (43\%) lasted only for eight consecutive hours with a limited number lasting as long as $20 \mathrm{~h}$ and only two episodes persisting for $36 \mathrm{~h}$ each. By contrast, fog episodes persisted for longer periods during the foggy year (1979), with the majority persisting for 20 to $22 \mathrm{~h}$ and isolated episodes lasting up to $60 \mathrm{~h}$. During the foggiest year (1980) at Alexander Bay, over $80 \%$ of fog events lasted for more than $3 \mathrm{~h}$ 
whereas only $6 \%$ of the events persisted for this length of time during the year with a low FDF (1982). A similar trend was apparent in other low fog and foggy years at both stations.

\section{Fog intensity}

The intensity of fog is one of its most important characteristic since it determines visibility. The degree of visibility depends on the opacity of the air, resulting from the number of particles held in suspension (Hewitt and Burton, 1971). It is defined as "the greatest distance at which a dark object can be seen and identified for what it is against the horizon" (SAWB, 1982)

Fog intensity data were only available for the three first order stations, Cape Columbine, Alexander Bay and Port Nolloth. Table 2 gives an indication of fog intensity at these stations. At Port Nolloth thick fog accounts for $60 \%$ of the total episodes and at Cape Columbine, $53 \%$. At both stations the incidence of low intensity fog is very low $(<10 \%)$. At Alexander Bay, on the other hand, medium intensity fog is recorded more frequently (40\%) than both high (28\%) and low (32\%) intensity fog. This discrepancy in fog intensity between the stations probably reflects the differences in their locations.

\section{Collection and measurement of water yields}

In order to determine the volume of rainfall or fog water that can be collected from fog collectors and to identify the relationship between various factors and the water yield, a number of pilot fog water collectors were erected at suitable sites. The criteria used for this selection of test sites were:

the characteristics of fog events in terms of their frequency and duration;

the speed of onshore winds;

terrain characteristics;

accessibility; and

security.

The existence of qualified staff to record water collection rates and an operational weather station at or near the site were added incentives.

\section{Experimental sites}

Four sites, stretching from approximately $33^{\circ} 22^{\prime} \mathrm{S}$ in the vicinity of Darling, to north of the Olifants River mouth were initially selected for the erection of pilot fog collectors. The specific locations were Pampoenvlei, Cape Columbine, Lambert's Bay and Brand se Baai. All four sites were close to the sea (where high fog frequencies are expected), easily accessible by road and secure from vandals. In addition, pre-existing weather stations were located at the sites or else personnel were available to collect data on a daily basis.

The CSIR (Environmentek, Stellenbosch) became interested in initiating their own fog water collection project along the West Coast. They erected a fog collector at Kalkbaken se Kop within the Namakwa Sands terrain and approximately $3.5 \mathrm{~km}$ to the east of Brand se Baai and at Kleinsee. Thus, although not strictly part of the WRC funded project, the CSIR collected data from both Namakwa Sands sites and kindly made the results available on a regular basis.

Table 3 summarises some characteristics of the sites selected for the pilot project. In most cases, land tenure holders not only granted permission for the erection of the collectors, but supplied active assistance with their erection and, where possible, made data from their weather stations available.

\section{Structure of pilot fog collectors}

It should be noted that although the South African Fog Water Project was initiated in 1993, funding only became available during January 1995. All progress prior to this was achieved through the goodwill of a number of people. Thus the first collectors were donated to the project by Mr M van Schoor (Terramin (Pty) Ltd), who also designed and constructed them. Those erected after 1995 were built by Prof van Heerden and his team from the University of Pretoria and conform, to some extent, to the pilot fog collectors used by Cereceda and Schemenauer in South America (Schemenauer and Cereceda, 1994b). As previously mentioned, the CSIR (Mr M Struthers, CSIR, Stellenbosch) constructed and erected the fog collectors at Brand se Baai, Kalkbaken se Kop and Kleinsee.

In view of the fact that some of the collectors were donated to the project, it was deemed inappropriate to be prescriptive with regards to the design of the structure. However, the yields from the different structures were comparable since the collecting surfaces consisted of the same material.

\section{Van Schoor collectors (MvS)}

Each of the 'Van Schoor' fog collectors consisted of a flat rectangular screen with an area of around $4 \mathrm{~m}^{2}$ (each of the screens at Pampoenvlei, Cape Columbine and Lambert's Bay had an area of $3.6 \mathrm{~m}^{2}$ each, while that at Brand se Baai was $3.4 \mathrm{~m}^{2}$ ). The screen

\begin{tabular}{|l|c|c|c|}
\hline \multicolumn{4}{|c|}{ TABLE 2 } \\
Fog intensities at first order \\
West Coast stations \\
\hline & \multicolumn{3}{|c|}{ Intensity } \\
\cline { 2 - 4 } & $\mathbf{0}$ & $\mathbf{1}$ & $\mathbf{2}$ \\
\hline Cape Columbine & 8 & 39 & 53 \\
Port Nolloth & 10 & 30 & 60 \\
Alexander Bay & 32 & 40 & 28 \\
\hline \multicolumn{3}{|c|}{0 = low intensity; 1 = moderate intensity; } \\
$2=$ high intensity \\
\hline
\end{tabular}

TABLE 3

Characteristics of west coast pilot fog collection sites

\begin{tabular}{|c|c|c|c|c|c|}
\hline Site & $\begin{array}{l}\text { Approx Fog } \\
\text { Freq }\end{array}$ & Lat ( $\left.{ }^{\circ} \mathrm{S}\right)$ & Long $\left({ }^{\circ} \mathrm{E}\right)$ & Alt (m) & Land tenure \\
\hline Pampoenvlei & Unknown & $33^{\circ} 22^{\prime}$ & $18^{0} 15^{\prime}$ & 50 & $\begin{array}{l}\text { Private, } \\
\text { University of Stellenbosch }\end{array}$ \\
\hline Cape Columbine & 111 & $32^{\circ} 50^{\prime}$ & $17^{0} 51^{\prime}$ & 60 & Portnet \\
\hline Lamberts Bay & $>60$ & $32^{0} 06^{\prime}$ & $18^{0} 17^{\prime}$ & 60 & Dept. Agric \\
\hline Brand se Baai & $>60$ & $31^{0} 18^{\prime}$ & $17^{0} 53^{\prime}$ & 42 & Namakwa sands \\
\hline Kalkbaken se Kop & $>60$ & $31^{0} 18^{\prime}$ & $17^{0} 55^{\prime}$ & 160 & Namakwa sands \\
\hline Kleinsee & Unknown & $29^{\circ} 40^{\prime}$ & $17^{0} 03^{\prime}$ & 33 & De Beers \\
\hline
\end{tabular}




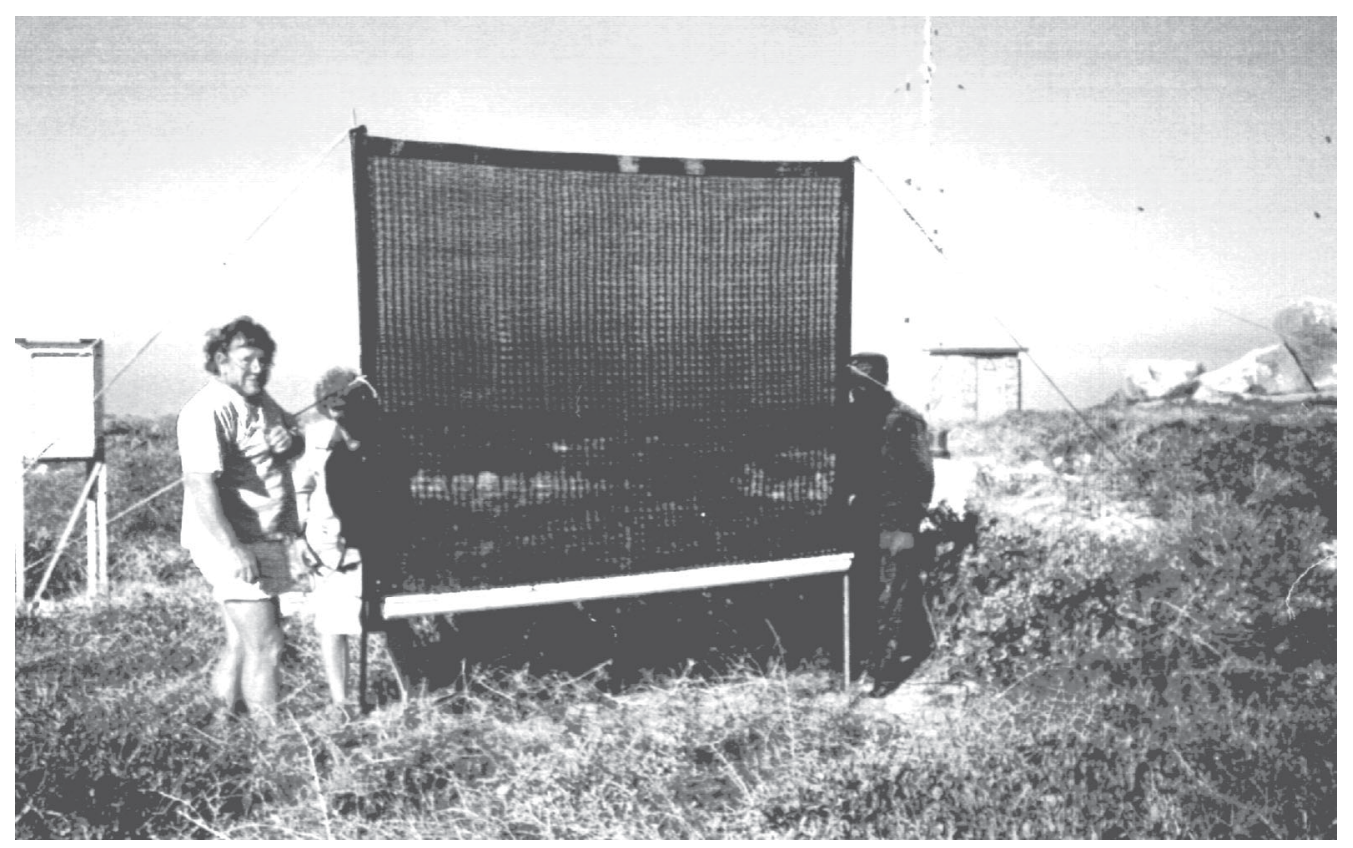

Figure 2

A Van Schoor fog water collector

consisted of a carbon impregnated polypropylene mesh imported from Kimre Inc., USA. This material has a three- dimensional structure designed to create vorticity in the air flow as it passes through the mesh. According to Kimre Inc. (1994) it is designed to collect droplets with diameters as small as 0.5 micron. The material is ultra-violet radiation resistant and has an expected life time of at least 10 years. All Kimre material was donated to the project by TERRAMIN. The screen was attached to an aluminium frame which was anchored to the ground by means of a number of guide ropes. During fog events, small fog droplets impinge on the screen, coalesce to form larger drops that flow downwards under the force of gravity into a gutter fixed to the frame below the screen. The gutter was tilted so that the water could run down towards a small pipe that emptied into a tipping bucket rain-gauge. At Pampoenvlei and Brand se Baai, this water was conducted via a plastic tube to a Keiki Seisakusho tipping bucket rain gauge, and the readings recorded on a Mike Cotton Systems (MCS) 120-02 data logger. At Cape Columbine and Lambert's Bay, the pipe emptied into a bucket placed below the collector. The volumes of water collected in the buckets during the previous $24 \mathrm{~h}$ were measured at 08:00 every morning using either a measuring cylinder or a $12.6 \mathrm{~cm}$ diameter rain gauge. Figure 2 illustrates the structure of a 'Van Schoor' fog collector.

\section{University of Pretoria collectors (UP)}

Figures $3 \mathrm{a}$ and $\mathrm{b}$ show a scale drawing of the collector and a photo of the actual structure, respectively. The area of $1 \mathrm{~m}^{2}$, is in line with the suggestion by Schemenauer and Cereceda (1994b). The screen was originally attached to an aluminium frame but tests at a high elevation site in the Northern Province indicated that it was too weak to withstand the high wind velocities. Steel frames were subsequently used at all sites.

In view of the remoteness of the sites, the lack of water there, and the difficulty in transporting building materials to these sites, it was decided that mounting the collectors on concrete bases would not be viable. Instead, the Department of Civil Engineering (University of Pretoria) laboratory staff prefabricated the concrete foundations by casting concrete in $25 \ell$ plastic drums. Robust $5 \mathrm{x}$ $50 \mathrm{~mm}$ angle iron brackets were cast in the concrete. The bases were dried in the concrete laboratory to reduce weight. The erection of the fog collector thus became a fairly easy operation. All that was required were two holes in the ground for the bases. The frame was bolted to the bases, leveled and soil stamped into the holes to fix the structure. The result was a rigid frame that withstood gale force winds without any significant sway or movement. An advantage of the system was that no anchoring cables were required provided the total height was under $2 \mathrm{~m}$.

The gutter was tilted slightly so that the water drained easily towards the hole fitted with a copper tube. From there, it was channeled via a plastic pipe to a tipping bucket, which was connected to a Field Event Data Logger (FEDL). This recorder is a micro controller based data logger with non-volatile memory and a real time clock. The data were unloaded from the logger with a laptop PC via a RS232 connection.

\section{The CSIR collectors}

The CSIR fog collectors were more sophisticated than the others (see Fig 4). The $1 \mathrm{~m}^{2}$ screens, with base heights at 2.5 and $7.5 \mathrm{~m}$, were also composed of the fine Kimre mesh. A relatively elaborate MCS weather station was erected at the Kalkbaken se Kop site. This comprised an MCS 120-02 Ex 8 channel data logger, a 1773 wind speed sensor at $3 \mathrm{~m}$ above the ground, a 167-2 wind direction sensor at $6 \mathrm{~m}$ above ground level, a 151 temperature sensor at 4,5 $m$ above the ground, two Davis tipping bucket rain gauges - one for measuring rainfall and the other for fog water collection - and an inline water filter (Struthers, 1997).

Separate rain gauges were installed at all the test sites and were used to measure rainfall amounts.

\section{Pilot project implementation}

Further modifications and additions were made to some of the existing collectors. These changes were for purposes of either verifying data or determining whether the yield varied with the height of the screen. 

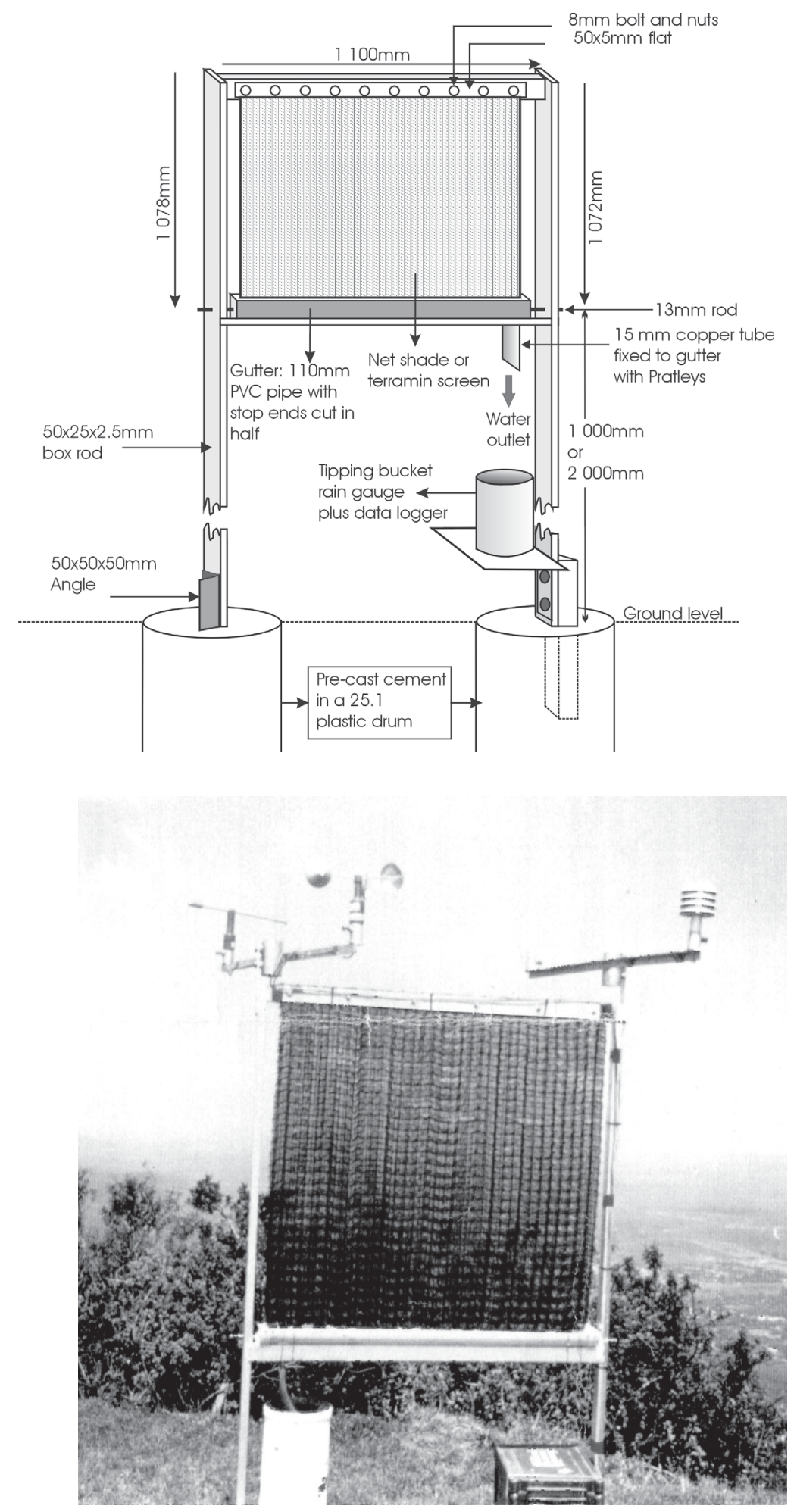

Figure 3

(a) Scale drawing and (b) photo of pilot collectors designed by the University of Pretoria team.

At Cape Columbine a second fog collector with area $1 \mathrm{~m}^{2}$ and base height $2 \mathrm{~m}$ was erected during April 1996. This was fitted with a tipping bucket which emptied into a separate bucket. Two sets of data were thus available for this smaller raised screen, namely, one set from the data logger which recorded volumes of water on a continuous basis and the other comprising the lighthouse-keeper's data which indicated the volumes of water that collected in the bucket. The data logger readings could thus be used to verify the accuracy of the lighthouse-keeper's readings while comparison of the large and smaller collectors could be used to determine the effect of raising the base of a collector. Unfortunately, there was a considerable turnover of lighthouse-keepers at Cape Columbine. This resulted - not only in a number of gaps in the data set - but in the mistaken dismantling of the large 'van Schoor' collector in October 1996.

At Kalkbaken se Kop, a raised collector and another wind speed sensor at $8 \mathrm{~m}$ above ground level were installed.

Unfortunately, the fog collector which was erected at Pampoenvlei during February 1994 never yielded results. Either the data logger malfunctioned or the screen was blown over or the pipes were clogged by sand and dust. The fog collector was thus dismantled towards the beginning of 1996.

The majority of sites thus had only one fog collector, whereas two were erected at Cape Columbine and at Kalkbaken se Kop.

Table 4 summarises information on the characteristics of the first fog collectors erected and subsequent modifications made at each of the sites.

\section{Data collection and analysis}

Monthly data summary forms were completed for each fog day at Cape Columbine and Lambert's Bay. They contained information on daily water yields, rainfall and wind data together with commencement and cessation times of fog episodes and their intensity. The summary report was forwarded to the project leader at the end of every month. For a short period, water-yield data for Cape Columbine were recorded using a tipping bucket and data logger. Weather data were collected from instruments in a Stevenson's screen. However, due to the remoteness of the sites, data logger data could only be collected when one of the team members was in the vicinity. This resulted in large amounts of data being lost.

At Kalkbaken se Kop and Brand se Baai, tipping bucket rain gauges and data loggers recorded fog water yields on a continuous basis. Fully automatic weather stations located in the immediate vicinity of the collecting site at each of these stations and at Pampoenvlei were used to collect weather data.

It should be pointed out that the water yield information supplied by the CSIR was limited to fog water yields whereas at Lamberts Bay and Cape Columbine both rainfall and fog deposition were collected. For these data, it was assumed that all deposition occurring on days without rain originated from fog. Although mist/ fog usually accompanies rain, it is not possible to distinguish between them without using elaborate equipment. It was decided to assume that all the precipitation collected on a rain day was due to rainfall alone. Despite the fact that this technique underestimates the amount of fog deposition, it was not considered to be a serious limitation since the principal aim of the project was to supply water - immaterial of its origin - to rural communities. 


\begin{tabular}{|c|c|c|c|c|c|c|c|}
\hline \multicolumn{8}{|c|}{$\begin{array}{l}\text { TABLE } 4 \\
\text { Summary of characteristics of pilot fog collectors at South African west coast sites }\end{array}$} \\
\hline \multirow[t]{2}{*}{ Site } & \multicolumn{3}{|c|}{ Original } & \multicolumn{4}{|c|}{ Modification } \\
\hline & Date & No/ Type & $\begin{array}{c}\text { Size }\left(\mathrm{m}^{2}\right) / \\
\text { material }\end{array}$ & Date & Modification & $\begin{array}{c}\text { Type/ } \\
\text { size }\left(\mathbf{m}^{2}\right)\end{array}$ & Material \\
\hline Pampoenvlei & $02 / 94$ & $1 \times \mathrm{MvS}$ & 3.6 / Kimre & $04 / 96$ & Dismantled & & \\
\hline Cape Columbine & $04 / 95$ & $1 \times \mathrm{MvS}$ & 3.6 / Kimre & $04 / 96$ & $\begin{array}{l}\text { Additional raised } \\
\text { UP collector } \\
\text { Base } h t=2.5 \mathrm{~m}\end{array}$ & & \\
\hline Lamberts Bay & $04 / 95$ & $1 \times \mathrm{MvS}$ & 3.6 / Kimre & - & & & \\
\hline Brand se Baai & $04 / 94$ & $1 \times \mathrm{MvS}$ & 3.4 / Kimre & - & & & \\
\hline Kalkbaken se Kop & $11 / 95$ & $\begin{array}{c}1 \times \text { CSIR } \\
\text { Base ht = } \\
2.5 \mathrm{~m}\end{array}$ & $1 /$ Kimre & $11 / 96$ & $\begin{array}{l}\text { Additional raised } \\
\text { collector } \\
\text { Base } \mathrm{ht}=7.5 \mathrm{~m}\end{array}$ & & \\
\hline Kleinsee & $11 / 95$ & $1 \times$ CSIR & 1 / Kimre & - & & & \\
\hline
\end{tabular}

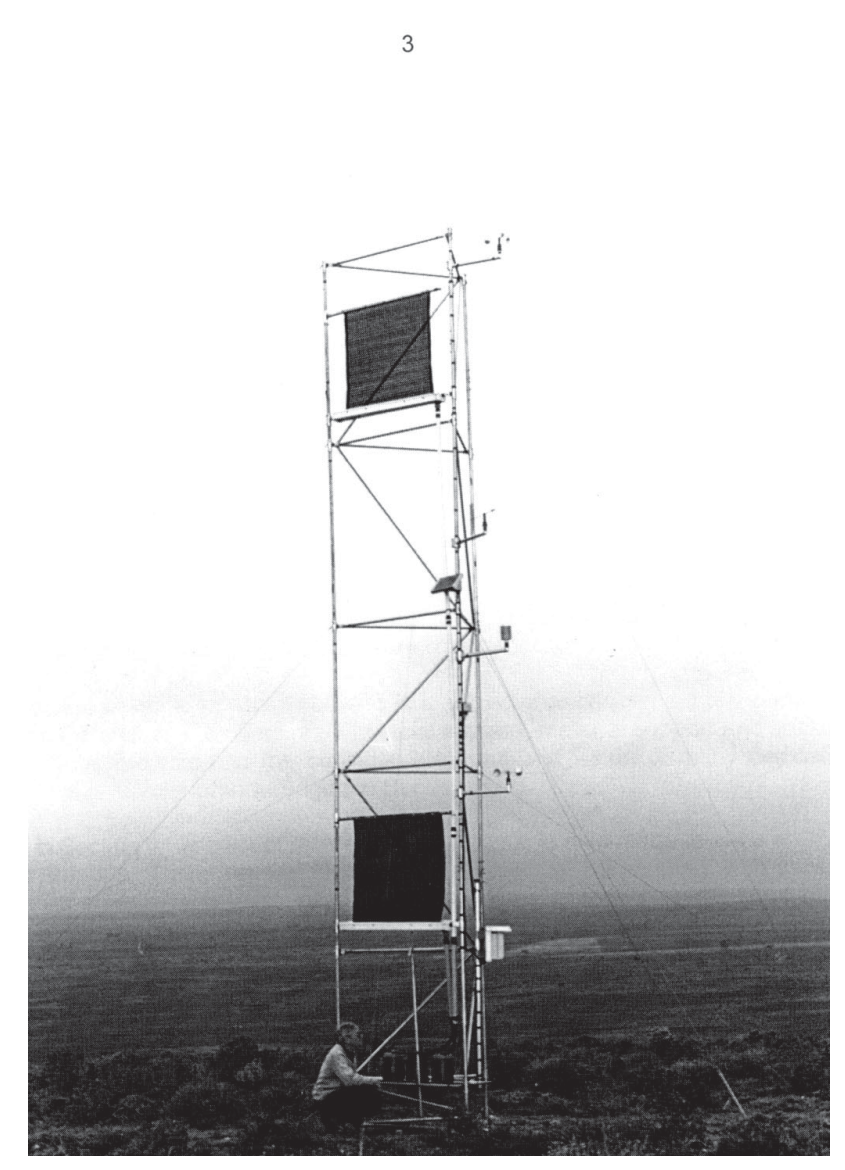

Figure 4

CSIR fog collectors at Kalkbaken se Kop (source: Struthers 1997)

Since the three types of collectors differed in size and structure and different methods and apparatus were used to record data, various conversions had to be performed in order to render data comparable. Volumes were thus recorded in litres or millimeters.
In the latter case, the standard rain gauge readings $(\mathrm{mm})$ were converted into litres by multiplying with a factor of 0.0125 .

\section{Results}

\section{Namakwa Sands sites}

At Brand se Baai, a total of $125.3 \ell$ of fog water were collected from the $3.4 \mathrm{~m}^{2}$ screen during the $342 \mathrm{~d}$ period spanning October 1995 to June 1997. This gives an average yield of $0.366 \mathrm{l} / \mathrm{m}^{2} / \mathrm{d}$. The highest daily rate was $0.69 \ell$ which was collected during March 1997.

During the six month period, from December 1996 to June 1997 , an average of $1.3 \ell$ of water were collected per square meter of collecting material per day at Kalkbaken se Kop.

These results are not directly comparable since they reflect yields for different periods. However, comparison between yields at Brand se Baai and Kalkbaken se Kop during corresponding periods reveals that the fog water yield at the latter station was considerably higher despite it being further away from the sea with $3.5 \ell$ being collected for each one litre at Brand se Baai (see Table 5). The only explanation for this is the increased elevation of the latter site, since its altitude is $118 \mathrm{~m}$ higher than that of Brand se Baai. This probably reflects the increase in wind speed as well as the higher liquid water content of fog with increase in altitude. The former is borne out by wind speed readings at the two sites. During March, April and May 1997, for instance, the mean wind speed at Brand se Baai was $4.3 \mathrm{~m} / \mathrm{s}$ in comparison with $5.2 \mathrm{~m} / \mathrm{s}$ at Kalkbaken se Kop. Although slight, this appears to be a significant increase in wind speed - and thus in the volume of air moving through the collector screen. This is to some extent borne out by differences in the water yields of the upper and lower screens at Kalkbaken se Kop (Table 6). For the lower screen, the average daily water yield was $1.84 \mathrm{l} / \mathrm{m}^{2}$ while the upper screen yielded 2.45 $\ell / \mathrm{m}^{2}$.

By carefully noting the times of rainfall events and the corresponding deposition, Struthers (1997) was able to differentiate between rainfall and fog yields at Kalkbaken se Kop. Figure 5 shows the results for seven such episodes. 


\begin{tabular}{|l|c|c|}
\hline \multicolumn{3}{|c|}{ TABLE 5 } \\
$\begin{array}{c}\text { Comparison between fog water yields }(\ell) \text { at } \\
\text { Brand se Baai and Kalkbaken se Kop for } \\
\text { corresponding periods between March and } \\
\text { June 1997 (Source: Struthers 1997) }\end{array}$ \\
\hline Period & $\begin{array}{c}\text { Brand se } \\
\text { Baai }\end{array}$ & $\begin{array}{c}\text { Kalkbaken } \\
\text { se Kop }\end{array}$ \\
\hline $03 / 03 / 97-03 /-4 / 97$ & 0.693 & 2.314 \\
$03 / 04 / 97-30 / 04 / 97$ & 0.341 & 1.343 \\
$30 / 04 / 97-03 / 06 / 97$ & 0.488 & 1.593 \\
\hline Ratio & 1 & 3.514 \\
\hline
\end{tabular}

The importance of fog compared to that of rainfall is evident. Only during the first period did rain water collection exceed that of fog. In general, fog was found to contribute around $72 \%$ (246.2 $\ell$ vs. $91.9 \ell$ rain) to the total volume of water collected on the lower collector. Thus, fog is clearly the dominant source of the water collected at Kalkbaken se Kop.

\section{Lambert's Bay}

Water yield data were available for the $3.6 \mathrm{~m}^{2}$ fog collector at the Nortier Experimental Farm for the period April 1995 to October 1997. Monthly totals are given in Table 7.

During this 945 day period, $161.73 \ell$ of water were collected. This reflects the total yield for 143 wet $($ rain + fog) days. The mean daily and wet day yields were a meager 0.17 and $1.13 \ell$, respectively. The highest monthly yield was $199.95 \ell$, which were collected during April 1997.

The winter fog day frequencies were surprisingly low, especially in view of the fact that the West Coast falls within a winter rainfall region. Unfortunately no long term rainfall or fog frequency records are available for Lambert's Bay and hence it was not possible to determine the extent to which these three years represented 'normal' conditions.

Analysis of fog vs. rainfall yields at Lambert's Bay showed that $130.80 \ell$ of water were collected on fog days in comparison to the $30.93 \ell$ assumed to originate from rainfall alone. Fog deposition was thus more than four times that of rainfall.

\section{Cape Columbine}

Table 8 shows the volumes of water collected on the $3.6 \mathrm{~m}^{2}$ fog collector between April 1995 and November 1996. During this 457 day period a total of $789.5 \ell$ of water were collected in 95 wet days. These figures give a mean of $8.31 \ell$ of water per wet day $(\mathrm{wd})$ and $1.7 \mathrm{l} / \mathrm{d}$. Since the screen has a surface area of $3.6 \mathrm{~m}^{2}$, the yield appears to be only $0.47 \ell$ or $2.31 \ell / \mathrm{m}^{2} / \mathrm{wd}$. Slightly higher volumes were obtained from the screen centred at $2 \mathrm{~m}$ above the ground. Comparison of the fog yields from the upper and lower collectors for corresponding periods revealed that the yield increased by a factor of approximately 2.2 if the collector was raised by one meter.

However, detailed analysis of the data revealed serious shortcomings which cast doubt on the accuracy of the above results. For instance, for certain months, the lighthouse-keepers' summaries gave fewer wet days than were indicated on the official Weather Bureau records. These values sometimes differed by as much as $15 \mathrm{~d}$, with little or no coincidence in the dates of wet events. Seven out of the 16 months' data were found to be either incomplete
TABLE 6

Lower vs upper fog collector yields $(\ell)$ at Kalkbaken se Kop (2/12/96 - 30/6/97) (After Struthers 1997)

\begin{tabular}{|l|c|c|c|}
\hline Period & Days & $\begin{array}{c}\text { Total yield } \\
\text { at } \mathbf{2 . 5} \mathbf{~}\end{array}$ & $\begin{array}{c}\text { Total yield } \\
\text { at } \mathbf{7 . 5} \mathbf{~ m}\end{array}$ \\
\hline $2 / 12 / 96-7 / 1 / 97$ & 36 & 28.05 & 44.61 \\
$7 / 1 / 97-30 / 1 / 97$ & 23 & 9.22 & 14.92 \\
$30 / 1 / 97-20 / 2 / 97$ & 21 & 26.29 & 40.51 \\
$20 / 2 / 97-3 / 3 / 97$ & 11 & 20.52 & 30.83 \\
$3 / 3 / 97-3 / 4 / 97$ & 31 & 71.72 & 99.84 \\
$3 / 4 / 97-30 / 4 / 97$ & 27 & 36.28 & 48.48 \\
$30 / 4 / 97-30 / 6 / 97$ & 34 & 54.13 & 77.91 \\
\hline Total & 183 & 246.21 & 357.06 \\
\hline
\end{tabular}

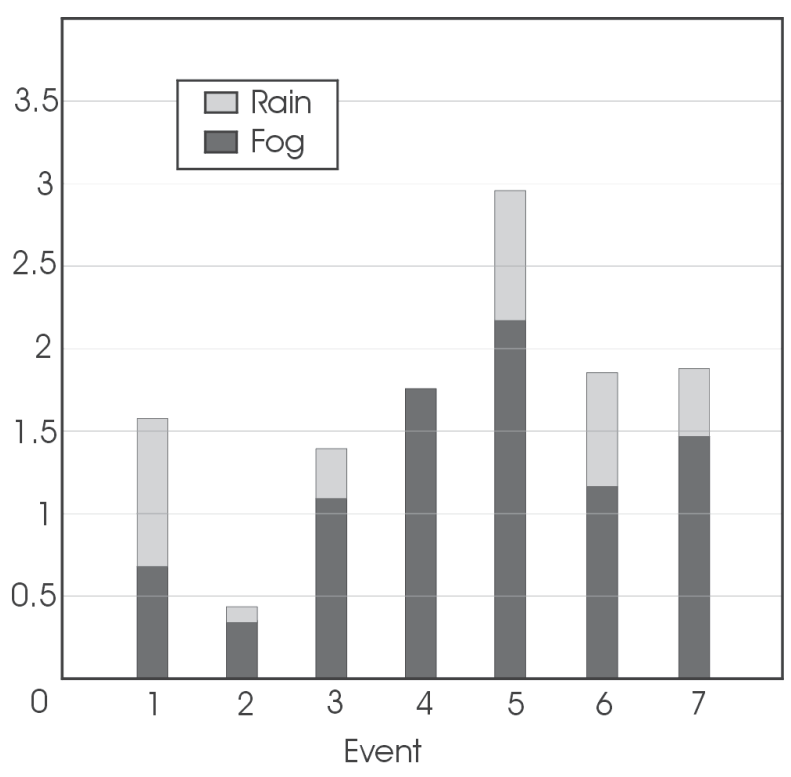

Figure 5

Rainfall vs fog water collection at Kalkbaken se Kop (02/12/96 - 03/06/97) (after Struthers 1997)

or inaccurate. Only nine months' data (274 d) could thus be used with certainty. During this period $692.3 \ell$ of water were collected on 82 wet days. This gives an average yield of $8.4 \ell / \mathrm{wd}(2.33$ $\ell / \mathrm{m}^{2} / \mathrm{wd}$ ) or $2.53 \ell /$ d (i.e. $0.70 \ell / \mathrm{m}^{2} \cdot \mathrm{d}$ ).

Careful scrutiny of the records for the nine months showed that $634.7 \ell$ of water were collected during 74 fog days (fd) (Table 8 Columns $4 \& 5$ ). This gives an average yield of $8.6 \mathrm{l} / \mathrm{fd}$. The remaining $57.6 \ell$ of water (692.3 - 634.7) obviously resulted from rainfall. During this period more that $90 \%$ of the water collected on the vertical collectors at Cape Columbine originated from fog alone.

Table 8 also shows that the total water yield is higher during months with a greater number of wet days $(r=0.82)$, but there is no linear relationship between FDF and the fog water yield $(r=0.37)$ This is probably due to variations in the intensity and duration of different fog events.

The actual volume of yields collected at Cape Columbine may be even greater than that indicated above. According to a number of workers at the lighthouse, the $25 \ell$ collecting bucket regularly 


\begin{tabular}{|c|c|c|c|c|c|c|c|c|c|c|c|c|c|}
\hline \multicolumn{14}{|c|}{$\begin{array}{c}\text { TABLE } 7 \\
\text { Summary of yields at Lamberts Bay April } 1995 \text { - October } 1997 \\
\text { Upper value = yields in liters; lower value = frequency of fog days }\end{array}$} \\
\hline $\mathrm{Yr}$ & Jan & Feb & Mar & Apr & May & Jun & Jul & Aug & Sep & Oct & Nov & Dec & Tot \\
\hline 1995 & & & & $\begin{array}{c}6.59 \\
3\end{array}$ & $\begin{array}{c}6.05 \\
4\end{array}$ & $\begin{array}{c}7.91 \\
7\end{array}$ & $\begin{array}{c}2.53 \\
5\end{array}$ & $\begin{array}{c}17.46 \\
7\end{array}$ & $\begin{array}{c}3.76 \\
6\end{array}$ & $\begin{array}{c}0.04 \\
1\end{array}$ & $\begin{array}{c}1.72 \\
4\end{array}$ & $\begin{array}{c}4.74 \\
7\end{array}$ & $\begin{array}{c}50.80 \\
44\end{array}$ \\
\hline 1996 & $\begin{array}{c}4.36 \\
10\end{array}$ & $\begin{array}{c}6.99 \\
8\end{array}$ & $\begin{array}{c}9.90 \\
11\end{array}$ & $\begin{array}{c}3.41 \\
5\end{array}$ & $\begin{array}{c}7.10 \\
7\end{array}$ & $\begin{array}{l}0 \\
0\end{array}$ & $\begin{array}{l}0 \\
0\end{array}$ & $\begin{array}{c}1.73 \\
3\end{array}$ & $\begin{array}{c}0.33 \\
1\end{array}$ & $\begin{array}{c}0.43 \\
1\end{array}$ & $\begin{array}{l}0 \\
0\end{array}$ & $\begin{array}{c}0.09 \\
1\end{array}$ & $\begin{array}{c}34.34 \\
47\end{array}$ \\
\hline 1997 & $\begin{array}{c}0.55 \\
5\end{array}$ & $\begin{array}{c}1.96 \\
4\end{array}$ & $\begin{array}{c}16.93 \\
12\end{array}$ & $\begin{array}{c}19.95 \\
12\end{array}$ & $\begin{array}{c}7.96 \\
5\end{array}$ & $\begin{array}{c}10.20 \\
2\end{array}$ & $\begin{array}{c}2.9 \\
2\end{array}$ & $\begin{array}{c}5.14 \\
3\end{array}$ & $\begin{array}{c}9.94 \\
5\end{array}$ & $\begin{array}{c}1.06 \\
2\end{array}$ & & & $\begin{array}{c}76.59 \\
52\end{array}$ \\
\hline
\end{tabular}

\begin{tabular}{|c|c|c|c|c|}
\hline \multicolumn{5}{|c|}{$\begin{array}{c}\text { TABLE } 8 \\
\text { Contribution of fog to total water yields at Cape } \\
\text { Columbine (April } 1995 \text { - November 96) }\end{array}$} \\
\hline Year month & $\begin{array}{c}\text { Total } \\
\text { yield }(\ell)\end{array}$ & $\begin{array}{l}\text { Wet } \\
\text { days }\end{array}$ & $\begin{array}{l}\text { Fog } \\
\text { yield }(\ell)\end{array}$ & $\begin{array}{l}\text { Fog } \\
\text { days }\end{array}$ \\
\hline $1995 \begin{array}{l}\text { April } \\
\text { May } \\
\text { June* } \\
\text { July* } \\
\text { Sept* } \\
\text { Oct* } \\
\text { Nov } \\
\text { Dec }\end{array}$ & $\begin{array}{c}24.8 \\
116.0 \\
27.0 \\
12.0 \\
22.0 \\
3.0 \\
16.7 \\
80.1\end{array}$ & $\begin{array}{c}7 \\
11 \\
3 \\
1 \\
3 \\
1 \\
9 \\
12\end{array}$ & $\begin{array}{l}20.7 \\
91.5\end{array}$ & $\begin{array}{c}9 \\
12\end{array}$ \\
\hline $1996 \begin{array}{l}\text { Jan } \\
\text { Feb } \\
\text { March } \\
\text { April } \\
\text { May } \\
\text { June* } \\
\text { Sept* } \\
\text { Nov* }\end{array}$ & $\begin{array}{c}113.6 \\
109.1 \\
66.2 \\
88.8 \\
77.0 \\
19.7 \\
10.9 \\
2.6\end{array}$ & $\begin{array}{c}10 \\
9 \\
9 \\
7 \\
8 \\
3 \\
1 \\
1\end{array}$ & $\begin{array}{c}97.4 \\
109.1 \\
63.4 \\
88.0 \\
67.0\end{array}$ & $\begin{array}{l}9 \\
9 \\
8 \\
7 \\
7\end{array}$ \\
\hline Total & 789.5 & 95 & 634.7 & 74 \\
\hline
\end{tabular}

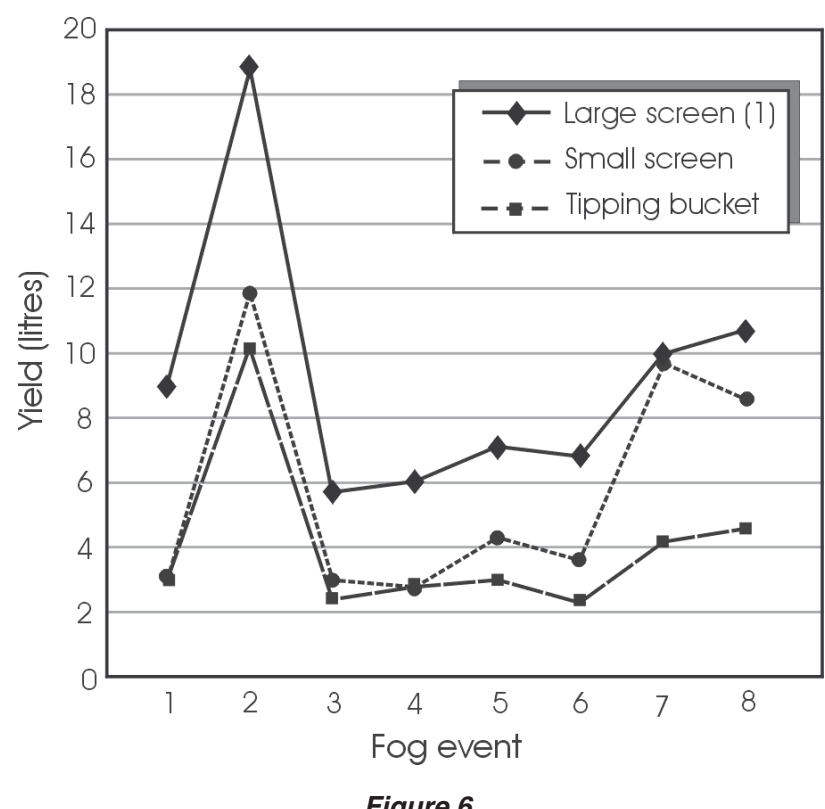

Data logger vs manually recorded data at Cape Columbine during April and May 1996

- Per $\mathrm{m}^{2}$ of collecting surface, the true yields (obtained from the data logger) were 1.4 times greater than those recorded by the lighthouse-keeper and 2.25 more than those for the larger, but lower, screen. Figure 6 shows that the greatest discrepancy occurred on high yield days. This is quite understandable when it is kept in mind that the lighthouse-keeper often had to decant more than $10 \ell$ of water into a rain gauge with a maximum capacity of $100 \mathrm{~mm}$. The likelihood of spillage and incorrect recording was thus higher the greater the volume of water collected.

often observed under the screen early the next morning. This is borne out by the fact that the vegetation in the immediate vicinity of the screen is noticeably taller than that some meters away. Fortunately both data logger and lighthouse-keeper data for the $1 \mathrm{~m}^{2}$ screen were available for a short period (13 April to 18 May, 1996) and could be used to verify the accuracy of the data used in the above calculation. During this period, the data logger recorded an average water collection rate of $22.57 \ell / \mathrm{fd}$ and $1.24 \ell / \mathrm{d}$. The highest hourly and daily yields were 1.6 and $10 \ell$, respectively.

This is considerable more than was recorded by the lighthousekeeper. The discrepancy is partially explained by Fig. 6 which shows a comparison of the yields recorded by the tipping bucket and those measured by the lighthouse-keeper. This revealed that:

- There were actually more fog days (according to data logger records) than were indicated by the lighthouse-keeper. It is thus clear that, despite assurances to the contrary, volumes were not measured every day.

If it is assumed that the error was constant over the nine month period for which complete records are available, the actual yields from the large collector may have been as high as $5.7 \mathrm{l} / \mathrm{m}^{2} \cdot \mathrm{d}(2.53$ $x 2.25)$ or $18.9 \ell / \mathrm{m}^{2} \cdot \mathrm{wd}(8.4 \times 2.25)$. A fog collector with an area of say $50 \mathrm{~m}^{2}$ could thus yield around $104000 \ell$ per year. This could make a significant contribution to the water supply in water-poor communities, provided that the quality of the water is acceptable.

\section{Water quality}

Two water samples were collected from Cape Columbine - on 24 August 1997 and on 18 May 1998 - and sent to the CSIR in Stellenbosch for chemical and microbiological analysis. The results 
of the analyses are given in Table 9.

A most important finding was that the water was free from any disease-causing organisms (E. coli) and therefore does not constitute a health hazard. The high counts of heterotrophic organisms are not significant since there is no specified maximum allowable limit. Moreover, these organisms can be removed using a simple sand filter.

The sodium chloride content was extremely high in the first sample. As this might have been due to contamination by windblown salt deposited on the collector during dry conditions, the lighthousekeeper was asked to wash down the screens prior to collecting the second sample. The second sample is thus a true reflection of the quality of the water collected on the fog collector.

The difference in water quality is marked. The total dissolved solids (TDS) have decreased from almost $9000 \mathrm{mg} / \ell$ to 288 $\mathrm{mg} / \ell$. If this criterion alone is taken into account, water from the second sample has ideal water quality (TDS conc. $<450 \mathrm{mg} / \ell$ (WHO, 1993)). However, it is not necessarily the TDS level but the concentration of specific ions that is detrimental to health (Department of Water Affairs, 1986). Fortunately, the concentrations of all ions are considerably less in the second sample the sodium ion concentration having decreased from $2522 \mathrm{mg} / \ell$ to only $44 \mathrm{mg} / \ell$. The calcium present in the water is probably the residue of the tap water used to wash down the screen. Analysis of the second sample thus indicates that the water collected on the fog screens is potable and fit for human consumption (DWAF 1996; Kempster et al., 1997).

As windblown salt deposition clearly occurs on collectors located close to the sea, it is assumed that this problem will not be experienced when the site is further inland. In an operational system, some mechanism will have to be introduced to allow the first water collected during a wet event to be discarded.

\section{Conclusion}

Preliminary findings for the four West Coast experimental stations indicated that the water collection rates at Cape Columbine were similar to those at Kalkbaken se Kop and considerably higher that at the other sites. However, more detailed scrutiny of the records revealed certain inaccuracies and inadequacies in the Cape Columbine data set. When using the most reliable data, it appears that the daily water yield could be as high as $5.7 \mathrm{l} / \mathrm{m}^{2}$ of collecting surface. This compares favourably with yields obtained in Chile. Unfortunately, no information is available for fog collection at coastal sites in Namibia (Shanyengana et al., 2001).

The expected annual water yields from fog collectors at Cape Columbine could thus be between 5.7 × $365=2080 \ell$ and $18.9 \times 110$ $=2079 \mathrm{l} / \mathrm{m}^{2}$ of collecting surface - a substantial volume of water which could be made available to the water-poor communities along the West Coast. If a similar array of fog collectors to that in Chile could be erected at Cape Columbine, i.e. 75 screens, each with a surface area of $48 \mathrm{~m}^{2}$ and bases $2 \mathrm{~m}$ above the ground, a yield of around $7.5 \times 10^{6} \ell$ of potable water could be expected per annum. This is sufficient to supply more than 600 people with $30 \ell$ of water every day.

This could make a significant impact on the quality of life of the people living in the area and, if sufficient collectors were erected, the water could be used to start various small-scale agricultural projects. With sufficient water, the abundance of sunshine and the absence of other natural hazards such as hail and frost, the selection of appropriate crops could generate a substantial income and significantly improve the quality of life of the community.

Other West Coast communities could also benefit from harvesting fog water. Prerequisites for the successful implemen-

\begin{tabular}{|c|c|c|}
\hline \multicolumn{3}{|c|}{$\begin{array}{c}\text { TABLE } 9 \\
\text { Chemical and microbial analysis of } \\
\text { Cape Columbine fog water }\end{array}$} \\
\hline Chemical analysis & $\begin{array}{r}\text { Date: } \\
\text { 24/8/97 }\end{array}$ & $\begin{array}{r}\text { Date: } \\
18 / 5 / 98\end{array}$ \\
\hline 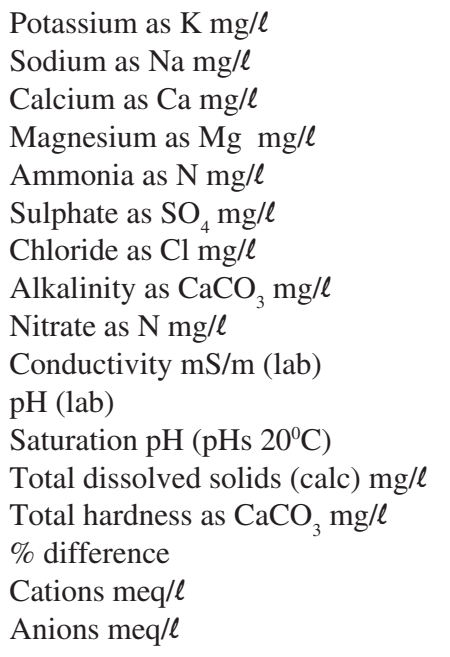 & $\begin{array}{r}89.3 \\
2522.0 \\
151.0 \\
308.0 \\
3.0 \\
674.0 \\
4692.0 \\
56.0 \\
13.2 \\
1400.0 \\
6.5 \\
7.8 \\
8960.0 \\
1648.0 \\
2.29 \\
145.14 \\
148.46\end{array}$ & $\begin{array}{r}1.9 \\
44.0 \\
33.0 \\
5.7 \\
0.3 \\
17.0 \\
77.0 \\
177.0 \\
0.4 \\
45.0 \\
7.3 \\
8.0 \\
288.0 \\
106.0 \\
1.86 \\
4.81 \\
4.89\end{array}$ \\
\hline \multicolumn{3}{|l|}{ Microbial analysis } \\
\hline $\begin{array}{l}\text { Heterotrophic } \mathrm{P} / \mathrm{C} \text { po } 1 \mathrm{~m} \ell \text { at } 35^{\circ} \mathrm{C} \\
\text { Total coliforms per } 100 \mathrm{~m} \ell \\
\text { Faecal coliforms per } 100 \mathrm{~m} \ell\end{array}$ & $\begin{array}{r} \pm 450000 \\
0 \\
0\end{array}$ & - \\
\hline
\end{tabular}

tation of a fog water collection project are a high incidence of fog, the presence of wind during the fog episode and a suitable site.

Since West Coast fog is mostly confined to the coastal zone below the $200 \mathrm{~m}$ contour line with the mean annual fog incidence decreasing southwards and with distance from the sea, the most suitable areas for fog water harvesting should be found in the northern part of the region. However, the fact that the highest yields were measured at Cape Columbine in the south, emphasizes the fact that high fog incidence does not necessarily imply that high volumes of water can be collected. The origin of the fog, wind speed during fog events and elevation are major determinants in the volume of water that can be collected. Indeed, selection of a suitable site is vital to the success of a fog water harvesting project.

\section{Acknowledgments}

I sincerely thank the Water Research Commission for their financial support. Without this, the research would not have been possible. Thanks also to the other essential contributors - Ms Maureen Charlton for assistance with the analysis of the geographic characteristic of fog in South Africa; Kimre Inc. who donated the material used for all fog collector screens; Mr Martin van Schoor, for his participation, support and generosity; Namakwa Sands and PortNet for allowing use of their terrain; Mr Johan Grobler, the lighthouse-keepers and the farmers comprising the Fog Watch Network - for kindly collecting data; the CSIR, and in particular Mike Struthers, for their participation in the project, support, manipulation and supply of data; and most importantly, members of the research team, Dr Hannes Rautenbach and Prof Johan van Heerden for designing and constructing the fog collectors and for data collection. 


\section{References}

CERECEDA P and SCHEMENAUER RS (1988) The role of topography and wind flow in high elevation fog water collection. Paper presented at the $3^{\text {rd }}$ Int. Conf. on Southern Hemisphere Meteorology and Oceanography, Buenos Aires, Brazil.

CERECEDA P and SCHEMENAUER RS (1993) High elevation fog as a water supply for developing countries. Paper presented at the 6th Int. Conf. on Rainwater Catchment Systems, Nairobi, Kenya.

CERECEDA P, SCHEMENAUER RS and SUIT M (1992) An alternative water supply for Chilean coastal desert villages. Water Resour. Dev. 8 (1) 53-59.

COPENHAGEN WJ (1953) Periodic Mortality of Fish in the Walvis Bay Region: A Phenomenon of the Benguela Current. Investigative Report 14. Department of Fisheries, Pretoria.

CURRIE R (1953) Upwelling in the Benguela Current. Nature (London) 171 (4351) 497-500

DEPARTMENT OF WATER AFFAIRS (1986) Management of the Water Resources of the Republic of South Africa. Department of Water Affairs, Pretoria.

DEPARTMENT OF WATER AFFAIRS AND FORESTRY (1996) South Africa Water Quality Guidelines for Domestic Use ( $2^{\text {nd }}$ edn.). Pretoria.

ESTIE KE (1984) Forecasting the formation and movement of coastal lows. Paper presented at the Coastal Low Workshop, Simonstown, March 1984, 17-27.

ESTIE KE (1986) Fog in the Namib. Unpublished manuscript.

HENDERSON-SELLERS A and ROBINSON P (1986) Contemporary Climatology. Longman Scientific and Technical, New York.

HEWITT K and BURTON I (1971) The Hazardousness of a Place: A Regional Ecology of Damaging Events. University of Toronto Press.

HEYDOORN AE and TINLEY KL (1980) Estuaries of the Cape. Part 1: Synopsis of the Cape Coast. CSIR Research Report 380.

KEMPSTER PL, VAN VLIET HR and KUHN A (1997) The need for guidelines to bridge the gap between ideal drinking-water quality and that quality which is practically achievable and acceptable. Water $S A$ 23 (2) 163-167.

KERFOOT O (1968) Mist precipitation on vegetation. For. Abstr. 29 $8-20$.

KIMRE INCORPORATED (1994) Mist \& Drift Eliminators Tower Packing \& Aerosol Separation. Perrine, Florida, USA. 8 pp.

LANCASTER J, LANCASTER N and SEELY M K (1984) Climate of the central Namib desert. Madoqua 14 (1) 5 - 61.

LINACRE E and HOBBS J (1977) The Australian Climatic Environment. John Wiley \& Sons, Brisbane.

LUTJEHARMS JRE and MEEUWIS JM (1987) The extent and variability of south east Atlantic upwelling. In: AIL Payne, JA Gullard and KH Brink (eds.) The Benguella and Comparable Ecosystems. S. Afr. J. Mar. Sci. 5 51-62.

LYDOLPH PE (1957) A comparative analysis of dry western littorals. Annal. Assoc. Am. Geog. 47 213-230.

MARLOTH R (1904) Results of experiments on Table Mountain for ascertaining the amount of moisture deposited from the SE clouds. Trans. SA Phil. Soc. 14 403-408.

MARLOTH R (1907) Results of further experiments on Table Mountain for ascertaining the amount of moisture deposited from the SE clouds. Trans. SA Phil. Soc. 16 97-105.

MEIGS P (1966) Geography of Coastal Deserts. UNESCO, Brussels

NAGEL JF (1956) Fog precipitation on Table Mountain. Quart. J. Roy. Meteorol. Soc. 82 452-460.

NAGEL JF (1959) Fog precipitation at Swakopmund. Weather Bureau Newsletter 125 1-9.

NAGEL JF (1962) Fog precipitation measured on Africa's southwest coast. Notos 11 51-60

NELSON-ESCH MS nd Mist as an economical source of potable water. Report: Solar Utilities Ltd, Benoni.

NELSON G and HUTCHINGS L (1983) The Benguela upwelling area. Prog. Oceanogr. 12 333-359.

NIEMAN WA, HEYNS C and SEELY MK (1978) A note on precipitation at Swakopmund. Madoqua 11 (1) 69-73.
OLIVIER J (1992) Some spatial and temporal aspects of fog in the Namib. SA Geographer 19 (1/2) 106-126.

OLIVIER J (1995) Spatial distribution of fog in the Namib. J. Arid Environ. 29 129-138.

OLIVIER J and VAN HEERDEN J (1999) The South African Fog Water Collection Project. WRC Report No. 671/1/99, Pretoria.

PRESTON-WHYTE RA and TYSON PD (1988) The Atmosphere and Weather of Southern Africa. Oxford University Press, Cape Town.

RUSH K, VAN HUYSSTEEN MRK and OLIVIER J (2000) Patterns of domestic water inadequacy on the South African West Coast. Water SA 26 (4) 537-554.

SAWB (SOUTH AFRICAN WEATHER BUREAU) (1982) Weather Codes for Land Stations (Surface Observations). South African Weather Bureau, Department of Environmental Affairs, Pretoria.

SAWB (SOUTH AFRICAN WEATHER BUREAU) (1986) Climate of South Africa. Climate Statistics up to 1984. WB40. Department of Environmental Affairs, Pretoria.

SAWB (SOUTH AFRICAN WEATHER BUREAU) (1987) Station Register Weather Observation Network. Department of Environmental Affairs, Pretoria.

SCHEMENAUER RS and CERECEDA P (1991) Fog-water collection in arid coastal locations. Ambio 20 (7) 303-308.

SCHEMENAUER RS and CERECEDA P (1994a) Fog collection's role in water planning for developing countries. Natl. Resour. Forum 18 (2) 91-100.

SCHEMENAUER RS and CERECEDA P (1994b) A proposed standard fog collector for use in high elevation regions. J. Appl. Meteorol. 33 1313-1322.

SCHEMENAUER RS, CERECEDA P and CARVAJAL N (1987) Measurements of fog water deposition and their relationships to terrain features. J. Clim. and Appl. Meteorol. 26 1285-1291.

SCHEMENAUER RS, FUENZALIDA H and CERECEDA P (1988) A neglected water resource: The Camanchaca of South America. Bull. Am. Meteorol. Soc. 69 138-147.

SCHULZE RE (1975) Catchment Evapotranspiration in the Natal Drakensberg. Unpublished PhD Thesis, University of Natal, Pietermaritzburg.

SCHUTTE JM (1971) Die Onttrekking van Water uit die Lae Wolke op Mariepskop. Technical note no. 20, Division of Hydrological Research, Department of Water Affairs, Pretoria.

SHANNON LV (1985) The Benguela ecosystem: Part 1. Evolution of the Benguela, physical features and processes. In: M Barnes (ed.) Oceanography and Marine Biology. An Annual Review 24 65-170.

SHANYENGANA ES, HENSCHEL JR, MTULENI VS, MWENYA E and SEELY MK (2001) Exploring fog as a supplementary water source in Namibia. Proc. $2^{\text {nd }}$ Int. Conf. on Fog and Fog Collection, St John's, Canada.

SNOW CS (1985) Mist Interception by Three Species of Mountain Fynbos. Unpubl. M.Sc. Dissertation, Dept. of Environmental and Geographical Sciences, University of Cape Town.

STOCKTON PL (1988) Aspects of the Filament Activity within the Benguela Upwelling System. Unpublished MA Thesis, University of Stellenbosch.

STRUTHERS MJ (1997) Water from fog study on the Cape West Coast. Progress Report: December 1995 to May 1997. CSIR Report ENV/S197018.

TOENS PD, STADLER W and WULLSCHLEGER NJ (1999) The Association of Groundwater Chemistry and Geology with Atypical Lymphocytes (as a Biological Indicator) in the Pofadder Area, North Western Cape, South Africa. Final Report No. K5/839, Water Research Commission, Pretoria.

VENDRIG M (1990) Fog Occurrence and Measurement in Namibia. Unpubl. Honours Research Project, Department of Geography and Environmental Studies, University of the Witwatersrand.

WALKER ND, TAUNTON-CLARK J and PUGH J (1984) Sea temperatures off the South African West Coast as indicators of Benguela warm events. S. Afr. J. Sci. 80 (2) 72-77.

WHO (1993) Guidelines for Drinking-water Quality. Vol 1: Recommendations ( $2^{\text {nd }}$ edn.) World Health Organisation, Geneva. 